\title{
Peak Expiratory Flow Rates in Children Under 5 Years of Age
}

\author{
A. D. MILNER and D. INGRAM \\ From The Hospital for Sick Children, Great Ormond St, London
}

Milner, A. D., and Ingram, D. (1970). Archives of Disease in Childhood, 45, 780. Peak expiratory flow rates in children under 5 years of age. An initial trial on children between 2 years 4 months and 4 years 9 months showed that good reproducible results for peak expiratory flow rates could be obtained from children over the age of 3 years using the low-range Wright Peak Flow Meter. Results on 92 normal children between the age of 3 and 5 years are reported.

The Wright Peak Flow Meter was initially designed for the Pneumoconiosis Unit of the Medical Research Council by Wright and McKerrow (1959) but rapidly gained wide acceptance as a useful aid for assessing airways obstruction in children and adults.

There have been several reports of results of peak expiratory flow rates in children using the standard meter (Nairn et al., 1962; Murray and Cook, 1963; Lunn, 1965; Dugdale and Moeri, 1968) and two reports of experience using the low-range model (Heaf and Gillam, 1962; Anderson, 1966), with a maximum flow rate of $2001 . / \mathrm{min}$. However, almost all the reports are from children over the age of 5 years. This paper presents the results of peak expiratory flow rates in 114 children under the age of 5 years, using the low-range model. 12 of the children suffered from cystic fibrosis and 10 from asthma. The remaining 92 were healthy children attending local play groups.

\section{Methods and Subjects}

The same low-range Wright Peak Meter ${ }^{\star}$ was used throughout and was calibrated against a rotameter with a range of 20 to $2001 . / \mathrm{min}$. Calibrations were repeated during and after the investigations and were not found to have altered. The calibration curve drawn from these results is given in Fig. 1.

This method of calibration is carried out under conditions of constant flow. However, the Wright Peak Flow Meter is used to record the peak flow rate during a rapidly changing flow situation. In view of this, the meter was also calibrated against a mercury pneumotachograph. The pneumotachograph was placed between the subject's mouth and the Wright Peak Flow

Received 5 May 1970.

^Airmed Ltd., Edinburgh Way, Temple Fields, Harlow, Essex.
Meter. The pressure drop across the pneumotachograph was measured by a Mercury M6 differential pressure manometer and displayed on an S.E. ultraviolet recorder. The subject then blew into the pneumotachograph and Wright Peak Flow Meter via a variable orifice to produce a wide range of values of peak expiratory flow. The pneumotachograph was calibrated by reference to a rotameter. Calibration by this method produced a wide scatter of results but the mean values were very similar to those obtained by direct calibration against the rotameter.

The children's heights and body weights were measured on each occasion after they had taken off their shoes and outdoor clothing. The children were given practice blows into the meter until at least three consistent

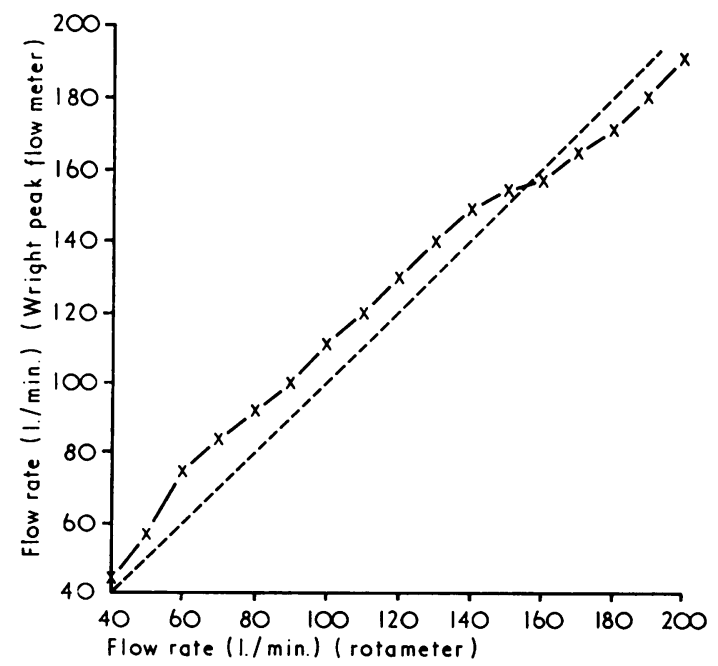

Fig. 1.-Calibration curve for low range Wright Peak Flow Meter. 
results were obtained. This would sometimes take several minutes with the younger children, but usually, particularly if a number of children were tested at the same time, this was achieved after a small number of attempts. Only the highest peak flow readings are given in the results (Nairn et al., 1962).

Preliminary studies were made on 14 healthy children aged 2 years 4 months to 4 years 9 months who attended a crèche in the Institute of Child Health. The objective was to assess the youngest age range at which representative and reproducible results could be obtained. Of these children, 1 aged 3 years 2 months refused repeatedly to take part, and 2 children aged 2 years 10 months and 3 years refused on one occasion but agreed on others. The other 4 children under 3 years were happy to co-operate but were unable to produce results representative of their peak expiratory flow rates. In view of this, only children over the age of 3 years and under 5 years were tested.

Ninety-three children aged 3 to 5 years attending a local Nursery School (St. Leonards, Coram Fields) were tested. 5 refused to co-operate and the results on a further 3 children were rejected on the grounds that they had had recurrent attacks of lower respiratory tract infection, leaving 85 normal children in whom there was nothing either in their medical reports or history of absenteeism to suggest that they would have abnormal lung function. Of the 92 children, including those attending the creche, 50 were boys and 42 girls.

The 12 children with cystic fibrosis and 10 children with asthma all attended The Hospital for Sick Children.

\section{Results}

Four children were tested on 4 separate occasions and 3 children on 3 occasions over the period of 1 month. The mean coefficient of variation for these results was $7 \cdot 8 \%$.

Tables I and II show the relation between height

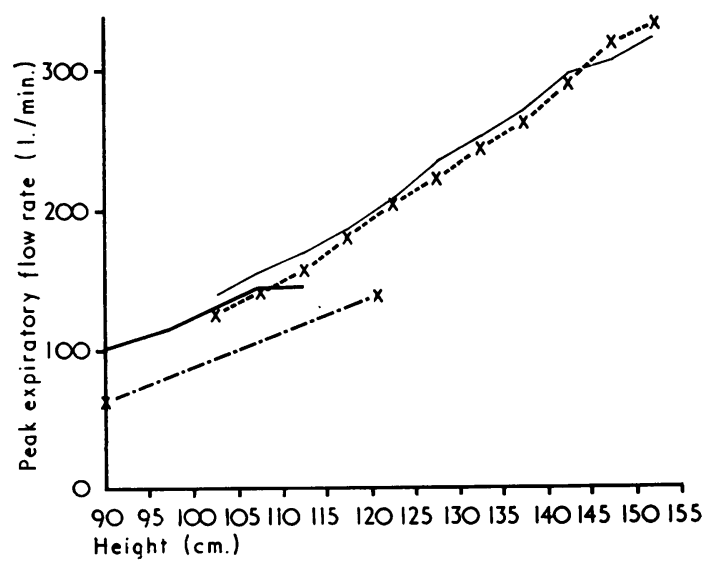

FIG. 2.-Mean peak expiratory flow rate related to height; present series (boys + girls) -; Lunn (1965) boys -, girls $x---x$; Rivera and Snider (1962) $x-.-. x$.
TABLE I

Mean Peak Flow Rates Related to Height in 92 Normal Children

\begin{tabular}{|c|c|c|c|c|}
\hline \multirow{2}{*}{ Height (cm.) } & \multirow{2}{*}{ Sex } & \multirow{2}{*}{$\begin{array}{l}\text { No. of } \\
\text { Children }\end{array}$} & \multicolumn{2}{|c|}{$\begin{array}{c}\text { Peak Flow Rates } \\
\text { (1./ min.) }\end{array}$} \\
\hline & & & Mean & $\begin{array}{l}\text { Standard } \\
\text { Deviation }\end{array}$ \\
\hline$<95$ & $\begin{array}{l}\text { Boys } \\
\text { Girls } \\
\text { Boys + Girls }\end{array}$ & $\begin{array}{r}2 \\
10 \\
12\end{array}$ & $\begin{array}{l}102 \cdot 5 \\
106 \cdot 5 \\
105 \cdot 8\end{array}$ & 19 \\
\hline 95-100 & $\begin{array}{l}\text { Boys } \\
\text { Girls } \\
\text { Boys + girls }\end{array}$ & $\begin{array}{r}9 \\
11 \\
20\end{array}$ & $\begin{array}{l}120 \cdot 5 \\
108 \cdot 4 \\
114\end{array}$ & $16 \cdot 9$ \\
\hline $100-105$ & $\begin{array}{l}\text { Boys } \\
\text { Girls } \\
\text { Boys + girls }\end{array}$ & $\begin{array}{l}21 \\
11 \\
32\end{array}$ & $\begin{array}{l}130 \cdot 4 \\
127 \cdot 8 \\
129 \cdot 6\end{array}$ & $23 \cdot 9$ \\
\hline $105-110$ & $\begin{array}{l}\text { Boys } \\
\text { Girls } \\
\text { Boys + girls }\end{array}$ & $\begin{array}{r}14 \\
8 \\
22\end{array}$ & $\begin{array}{l}144 \cdot 4 \\
137 \cdot 8 \\
141\end{array}$ & $21 \cdot 2$ \\
\hline $110-115$ & $\begin{array}{l}\text { Boys } \\
\text { Girls } \\
\text { Boys + girls }\end{array}$ & $\begin{array}{l}4 \\
2 \\
6\end{array}$ & $\begin{array}{l}139 \cdot 2 \\
150 \\
142 \cdot 8\end{array}$ & $22 \cdot 3$ \\
\hline
\end{tabular}

(cm.), age (months), and peak expiratory flow rate. As with previous series the best correlation was provided by height. Correlation values have not been given as they are misleading over this narrow range. As can be seen from Table $I$, the values for boys are higher than for girls when related to height. These results have also been plotted on Fig. 2 for

TABLE II

Mean Peak Rates Related to Age in 92 Normal Children

\begin{tabular}{|c|c|c|c|c|}
\hline \multirow{2}{*}{ Age (mth.) } & \multirow{2}{*}{ Sex } & \multirow{2}{*}{$\begin{array}{l}\text { No. of } \\
\text { Children }\end{array}$} & \multicolumn{2}{|c|}{$\begin{array}{c}\text { Peak Flow Rates } \\
\text { (1./min.) }\end{array}$} \\
\hline & & & Mean & $\begin{array}{l}\text { Standard } \\
\text { Deviation }\end{array}$ \\
\hline $35-40$ & $\begin{array}{l}\text { Boys } \\
\text { Girls } \\
\text { Boys + Girls }\end{array}$ & $\begin{array}{r}4 \\
8 \\
12\end{array}$ & $\begin{array}{l}130 \\
103 \\
113 \cdot 4\end{array}$ & $23 \cdot 3$ \\
\hline $40-45$ & $\begin{array}{l}\text { Boys } \\
\text { Girls } \\
\text { Boys + Girls }\end{array}$ & $\begin{array}{r}12 \\
9 \\
21\end{array}$ & $\begin{array}{l}122 \cdot 5 \\
102 \cdot 3 \\
113 \cdot 8\end{array}$ & $26 \cdot 8$ \\
\hline $45-50$ & $\begin{array}{l}\text { Boys } \\
\text { Girls } \\
\text { Boys + Girls }\end{array}$ & $\begin{array}{l}11 \\
10 \\
21\end{array}$ & $\begin{array}{l}127 \cdot 8 \\
125 \cdot 9 \\
127 \cdot 0\end{array}$ & $16 \cdot 3$ \\
\hline $50-55$ & $\begin{array}{l}\text { Boys } \\
\text { Girls } \\
\text { Boys + Girls }\end{array}$ & $\begin{array}{r}16 \\
9 \\
25\end{array}$ & $\begin{array}{l}139 \cdot 7 \\
131 \\
136 \cdot 4\end{array}$ & $21 \cdot 8$ \\
\hline $55-60$ & $\begin{array}{l}\text { Boys } \\
\text { Girls } \\
\text { Boys + Girls }\end{array}$ & $\begin{array}{r}7 \\
6 \\
13\end{array}$ & $\begin{array}{l}139 \\
149 \\
143 \cdot 4\end{array}$ & $23 \cdot 4$ \\
\hline
\end{tabular}


comparison with values reported by Lunn (1965) on 3556 Sheffield schoolchildren and Rivera and Snider (1962) who measured peak expiratory flow rates in 30 normal children using a pneumotachograph system. Rivera's results are considerably lower than those in this series, but there is good agreement between our figures and those of Lunn (1965). The results of peak expiratory flow rates in 12 children with cystic fibrosis and 10 children with asthma were widely scattered, but only 3 of the children with cystic fibrosis and only 1 of the children with asthma have values above the mean for for normal children of their height.

\section{Discussion}

In the past 20 years many sophisticated methods have been developed for assessing respiratory function in children over the age of 5 years and under the age of 6 months. However, children between these ages have been largely neglected as they are unable to co-operate sufficiently to produce satisfactory results using the system suitable for older children, and they will not tolerate the methods applicable to babies. Cherniack (1962) has included 14 children aged 3 years and 13 children aged 4 years in his paper on normal values for vital capacity, maximum breathing capacity, and maximum mid-expiratory flow rates in normal children, and Lunn (1965) has reported 47 children aged 4 years in his large series of respiratory measurements on normal school children. However, in our experience the majority of children under 5 years have difficulty in breathing out to residual volume, and their attempts at maximum breathing capacity tend to be lower than the expected. Results with the Wright Peak Flow Meter have been much more encouraging, and over the age of 3 years only the occasional child refuses to blow into the meter or loses interest before he has mastered the technique. The presence of other children tends to overcome any initial reluctance on the part of a shy child, but we have always eventually managed to obtain satisfactory results on children attending the hospital with respiratory diseases, even if tested unaccompanied byother children.

Our values on normal children are in close agreement with those reported by Lunn (1965) who used the standard peak flow meter, but are considerably higher than the results of Rivera and Snider (1962). This may be partly because children of this age find the Peak Flow Meter easier to use than the pneumotachograph system.
As has been found with older children the scatter of results is wide. This tends to reduce the value of this test as an absolute method for assessing airways obstruction. Results from children with asthma and cystic fibrosis are low relative to those from normal children, but less than $20 \%$ of children with cystic fibrosis had results more than $2 \mathrm{SD}$ below the expected. $50 \%$ of the children with asthma had values more than $2 \mathrm{SD}$ below the mean normal.

We have found the peak flow meter useful in monitoring young children admitted to the ward with severe bronchospasm, and also for assessing response to bronchodilators in children down to the age of 3 years.

Despite the problems of calibration and the wide scatter of normal values, the Wright Peak Flow Meter is a useful and relatively cheap aid for physicians managing children with respiratory disease, and is particularly valuable for assessing children between the ages of 3 years and 5 years as it provides information difficult to obtain by other means in this age-group.

We wish to thank Dr. D. Hull and Dr. A. P. Norman for their encouragement and advice; the headmistress and and children of St. Leonards Nursery School, Coram Fields, and Miss Drysdale and the children attending her Crèche at the Institute of Child Health for their help; and the Asthma Research Council for support.

\section{REFERENCES}

Anderson, J. P. (1966). The low-range flow meter used by school entrants. British fournal of Clinical Practice, 20, 635.

Cherniack, R. M. (1962). Ventilatory function in normal children. Canadian Medical Association fournal, 87, 80.

Dugdale, A. E., and Moeri, M. (1968). Normal values of forced vital capacity (FVC), forced expiratory volume (FEV 1.0.) and peak flow rate (PFR) in children. Archives of Disease in Childhood, 43, 229.

Heaf, P. J. D., and Gillam, P. M. S. (1962). Peak flow rates in normal and asthmatic children. British Medical fournal, 1, 1595.

Lunn, J. E. 1965). Respiratory measurements of 3,556 Sheffield schoolchildren. British fournal of Preventive and Social Medicine, 19, 115.

Murray, A. B., and Cook, C. D. (1963). Measurement of peak expiratory flow rates in 220 normal children from 4.5-18.5 years of age. Fournal of Pediatrics, 62, 186.

Nairn, J. R., Bennett, A. J., Andrew, J. D., and MacArthur, P. (1962). $A$ study of respiratory function in normal schoolchildren; the peak flow rate. Archives of Disease in Childhood, 36, 253.

Rivera, L. M., and Snider, G. L. (1962). Ventilatory studies in preschool children. I. Peak expiratory flow rate in normal and abnormal preschool children. Pediatrics, 30, 117.

Wright, B. M., and McKerrow, C. B. (1959). Maximum forced expiratory flow rate as a measure of ventilatory capacity. British Medical fournal, 2, 1041.

Correspondence to Dr. A. D. Milner, The Hospital for Sick Children, Great Ormond Street, London W.C.1. 